\title{
EKSPLORASI SIRIP MATAHARI SEBAGAI KONSEP MEREDUKSI SILAU MATAHARI DI GEDUNG KULIAH UNIVERSITAS BENGKULU
}

\author{
Panji Anom Ramawangsa ${ }^{{ }^{*}}$, Atik Prihatiningrum ${ }^{2}$ \\ Program Studi Arsitektur, Universitas Bengkulu ${ }^{1}$, \\ Program Studi Arsitektur, Universitas Bengkulu ${ }^{2}$ \\ e-mail: *1panjianom89@gmail.com, 2atikprihatiningrum@gmail.com
}

\begin{abstract}
Abstrak_Rasa nyaman merupakan salah satu bagian hal penting dalam kelangsungan hidup manusia dan salah satunya adalah kenyamaan visual dari pencahayaan alami. Gedung Kuliah Bersama V (lima) memiliki masalah kelebihan paparan matahari pada sisi samping fasad bangunan akibat pada posisi tersebut berada di sisi Barat dan Timur serta minimnya elemen pembayangan pada bangunan maka dibutuhkan solusi berupa desain sirip matahari sebagai pereduksi silau matahari yang berlebih terhadap bangunan. Metode yang digunakan adalah metode eksplorasi dengan membuat ragam bentuk sirip matahari dan menggunakan metode transformasi lipat dalam mengubah bentuk dasar sirip matahari menjadi bentuk baru dengan kriteria yang akan dicapai adalah jumlah tungkai penggerak bidang kurang dari 5 tungkai dengan bidang yang dapat berintegrasi dengan bentuk fasad. Hasil yang didapat adalah ragam bentuk sirip matahari yang didapat dari ekplorasi bentuk dasar sirip matahari dan pemilihan bentuk horizontal 1 yang sesuai dengan bentuk fasad gedung kuliah bersama V.
\end{abstract}

Kata kunci: Eksplorasi; Silau; Sirip Matahari.

\begin{abstract}
Feeling comfortable is an important part of human survival and one of them is the visual comfort of natural lighting. Kuliah Bersama $V$ (five) Building has the problem of excessive sun exposure on the side of the building facade due to the position being on the west and east sides and the lack of a shadowing element in the building so that a solution is needed in the form of a sun-shading design to reduce excessive sun glare on the building. The method used was an exploration method by making various forms of the sun shading and using the method of transformation of wrinkles, folding in changing the basic shape of the sun shading into a new form with the criteria to be achieved was the number of moving limbs of less than 5 limbs with fields that can be integrated with the shape facade. The results obtained were various forms of kinetic sun shading obtained from the exploration of the basic shape of the sun shading and the selection of the horizontal plane 1 shape by the shape of the facade Kuliah Bersama $\checkmark$ Building.
\end{abstract}

Keywords: Exploration; Glare; Sun-Shading

\footnotetext{
${ }^{1}$ Program Studi Arsitektur, Universitas Bengkulu

${ }^{2}$ Program Studi Arsitektur, Universitas Bengkulu
} 


\section{PENDAHULUAN}

Rasa nyaman merupakan salah satu bagian hal penting dalam kelangsungan hidup manusia dan salah satunya adalah kenyamaan visual dari pencahayaan alami. Kenyamanan visual terhadap kondisi pencahayaan alami sangat dibutuhkan dalam kehidupan sehari-hari termasuk dalam kegiatan belajar mengajar di dalam kelas. Hal ini selaras dengan standar yang telah ditetapkan oleh KEMENKES menyebutkan bahwa pencahayaan alami yang baik adalah pencahayaaan yang tidak menimbulkan kesilauan serta memiliki intensitas cahaya yang sesuai dengan peruntukannya (KEMENKES Nomor: 1405/MENKES/SK/XI/2002, 2002). Tidak dipungkiri bahwa intensitas cahaya alami yang baik menentukan kualitas daya serap mahasiswa dalam mengikuti proses belajar yang baik di dalam kelas (Masruchin dan Mufidah, 2019). Pencahayaan yang berlebih dapat mengakibatkan gangguan berupa kelelahan pada mata yang merupakan kondisi ketegangan pada mata yang diakibatkan indera penglihatan bekerja terlalu lama serta kondisi pandangan yang tidak nyaman yang bisa terjadi akibat beberapa faktor dan salah satunya adalah pencahayaan yang mengakibatkan kelelahan dan timbul rasa sakit pada mata serta rasa pening pada kepala (Prayoga, 2014).

Universitas Bengkulu merupakan salah satu perguruan tinggi negeri di Provinsi Bengkulu yang memiliki gedung belajar. Gedung belajar ini dipergunakan sebagai ruang aktifitas belajar mengajar bagi mahasiswa dan dosen. Salah satu gedung kuliah yang dimiliki oleh Universitas Bengkulu adalah Gedung Kuliah Bersama V (lima). Gedung ini difungsikan sebagai gedung kuliah Fakultas Teknik dan Fakultas MIPA. Gedung ini memiliki masalah kelebihan paparan matahari pada sisi samping fasad bangunan akibat letak bagian tersebut pada sisi barat dan timur, dan minimnya elemen pembayangan pada bangunan (Ramawangsa dan Prihatiningrum, 2019). Hal ini mengakibatkan silau dan suhu yang berlebih di dalam ruang kelas yang mengganggu aktifitas belajar mengajar sehingga aktifitas belajar tidak nyaman dan dapat mengurangi konsentrasi.

Berdasarkan permasalahan yang telah dijelaskan diatas, maka dibutuhkan solusi untuk mengendalikan silau matahari yang masuk ke dalam bangunan serta paparan yang berlebih pada sisi fasad bangunan. Terdapat beberapa solusi untuk mengendalikan silau yang terjadi pada bangunan yaitu orientasi lubang cahaya, posisi jendela, peneduh horizontal, tabir matahari dan menaikkan faktor refleksi (Ishak, 2013). Berdasarkan beberapa solusi diatas, maka dibutuhkan berupa sebuah elemen pembayangan pada Gedung Kuliah Bersama V dalam bentuk peneduh horizontal. Peneduh horizontal ini dalam bentuk desain sirip matahari sebagai pereduksi silau matahari yang berlebih terhadap bangunan serta sebagai strategi pendinginan pasif dan menjadi alternatif pemecah masalah dalam mengoptimalkan intensitas silau yang baik melalui penggunaan desain sirip matahari (Dewi, Budi dan Choirotin, 2018).

\section{METODE}

Metode yang digunakan dalam penelitian ini adalah metode eksplorasi. Kegiatan eksplorasi merupakan salah satu proses berpikir dan mengolah dari bermacam data yang kemudian diolah dalam bentuk ragam bentuk yang kemudian ditarik salah satu yang terbaik dari aneka data sebelumnya (Purwantiasning, 2014). Eksplorasi dilakukan terhadap bentuk dasar sirip matahari 
menjadi beragam bentuk variasi sirip matahari yang baru. Proses mengolah bentuk dasar sirip matahari menjadi bentuk baru menggunakan metode transformasi bentuk.

Transformasi bentuk merupakan metode manipulasi bentuk dengan cara mengubah dimensi atau dengan penambahan maupun pengurangan pada bidang (Ching, 2008). Metode transformasi dilakukan melalui pengolahan bentuk dasar geometri sirip matahari menjadi bentuk baru dengan menggunakan metode kerut, tekuk, dan lipat (Krier, 2001). Metode ini dilakukan dengan cara melakukan teknik lipat pada bentuk dasar geometri sirip matahari menjadi bentuk yang beraturan secara geometris.

Metode penyusunan kriteria capaian dalam pengolahan bentuk dasar geometri sirip matahari dirumuskan berdasarkan kategori-kategori teoritis yang telah ada. Kategori teoritis ini terdapat pada penelitian Strategy For Adaptive Kinetic Patterns : Creating A Generative Design For Dynamic Solar Shading Systems mengenai jumlah tungkai kinetik yang efisien pada pergerakan shading (Majed dan Alkhayyat, 2013) dan Eksplorasi Sun Shading Fasad Apartemen Dengan Metode Transfer Arsitektur Biomimetik (Implementasi Putri Malu) mengenai integrasi bentuk geometris didasari atas persamaan antar dua objek bentuk (Ramawangsa, Soemardiono dan Setijanti, 2015).

Proses pengolahan bentuk dasar dasar sirip matahari menjadi bentuk baru ini menggunakan software sketchup. Sketchup merupakan software permodelan 3D yang dikerjakan melalui komputer dalam mendapatkan membuat rupa, memberi tekstur hingga rendering (Saymote, 2016). Hasil ragam variasi sirip matahari yang telah diolah menggunakan software sketchup, kemudian dipilih untuk mendapat 1 (satu) model yang sesuai dengan permasalahan bangunan.
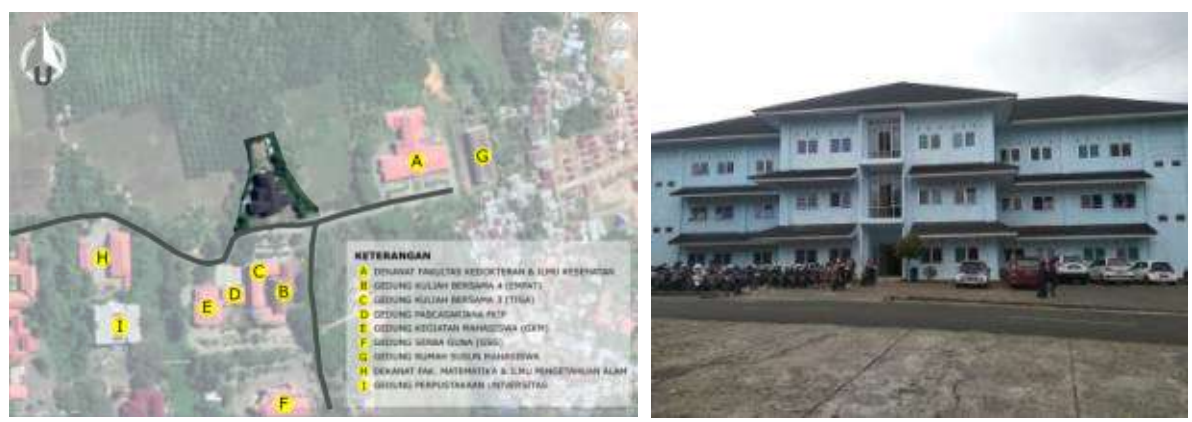

Gambar 1. Posisi Bangunan Gedung Kuliah Bersama V

Gedung Kuliah Bersama V Universitas Bengkulu ini terdiri dari 4 (empat) lantai dengan fungsi ruang yaitu ruang kelas belajar, ruang monitoring, ruang ujian, musholla dan toilet. Berdasarkan kondisi lapangan, sisi kelas terletak pada masing-masing sisi samping bangunan yang mengalami penyinaran berlebih ke dalam ruangan sehingga mengakibatkan gangguan kenyamanan visual.

\section{HASIL DAN PEMBAHASAN}

\section{A. Eksplorasi Bentuk Lipatan Geometris pada Sirip Matahari}

Konsep eksplorasi dilakukan dengan membuat ragam bentuk dasar sirip matahari yang masing-masing memiliki pola lipat yang berbeda untuk mencapai nilai efisien pergerakan serta jumlah intensitas cahaya yang masuk ke dalam bangunan serta membuat kriteria capaian untuk mendapat out put desain yang tepat terhadap permasalahan yang berada di Gedung Kuliah Bersama V. 
Jenis bentuk dasar sirip matahari terdiri atas 3 (tiga) yaitu, horizontal, vertikal dan egg crate (Lechner, 2001). Sehingga tahap eksplorasi diawali dengan transformasi 3 (tiga) bentuk dasar tersebut. Transformasi ini didasari atas efisiensi lipatan bukaan dan persentase bukaan bidang pada jendela. Proses transformasi bentuk dasar sirip matahari menjadi ragam bentuk baru dengan menggunakan metode transformasi lipat. Proses transformasi dijabarkan dalam gambar berikut ini.

\section{Sirip matahari horizontal 1}

Proses transformasi sirip matahari horizontal 1 dilakukan dengan membuat 1 (satu) bidang horizontal yang menutupi jendela. Pada bagian tengah bidang diletakkan 1 (satu) tungkai penggerak sebagai alat untuk melipat bidang.

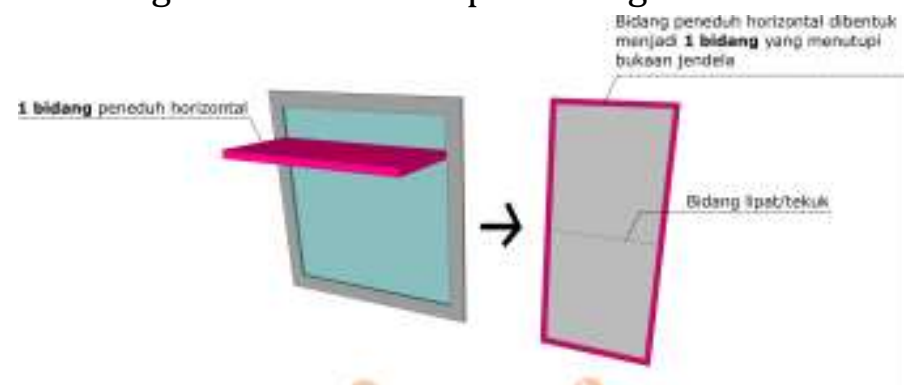

Gambar 2. Transformasi Sirip Matahari Horizontal 1, a) Sirip Matahari Horizontal, Dan B) Hasil Transformasi Sirip Matahari Horizontal 1

\section{Sirip matahari horizontal 2}

Proses transformasi sirip matahari horizontal 2 dilakukan dengan membuat 2 (dua) bidang horizontal dengan meletakkan 1 (satu) tungkai penggerak sebagai alat untuk melipat bidang pada masing-masing bidang.

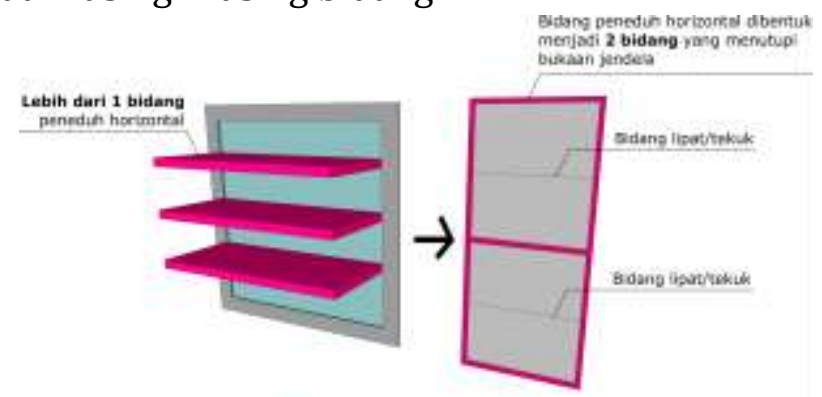

Gambar 3. Transformasi Sirip Matahari Horizontal 2, a) Sirip Matahari Horizontal, dan b) Hasil Transformasi Sirip Matahari Horizontal 2

\section{Sirip matahari horizontal 3}

Proses transformasi sirip matahari horizontal 3 dilakukan dengan membuat 3 (tiga) bidang horizontal yang membujur ke depan bukaan jendela. Pada masing-masing bidang diberikan 1 (satu) tungkai penggerak sebagai alat untuk melipat bidang. 


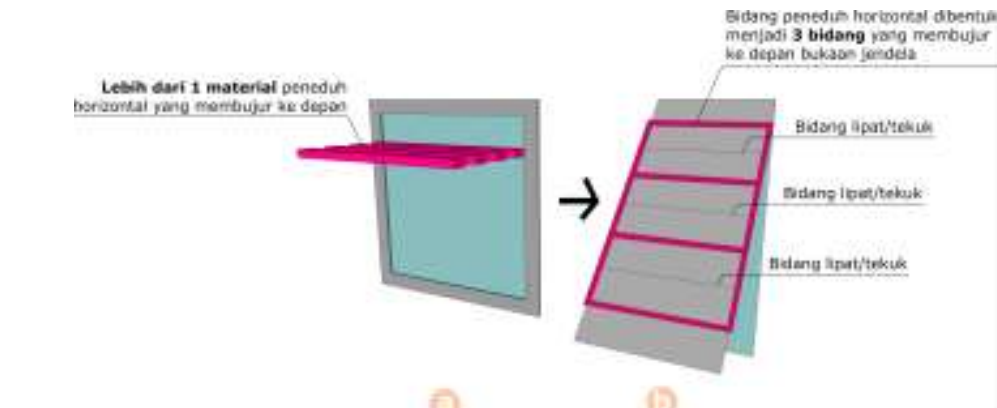

Gambar 4 . Transformasi Sirip Matahari Horizontal 3, a) Sirip Matahari Horizontal, dan b) Hasil Transformasi Sirip Matahari Horizontal 3

\section{Sirip matahari vertikal 1}

Proses transformasi sirip matahari vertikal 1 dilakukan dengan membuat 3 (tiga) bidang vertikal yang menutupi bukaan jendela. Pada masing-masing bidang diberikan 1 (satu) tungkai penggerak sebagai alat untuk melipat bidang.

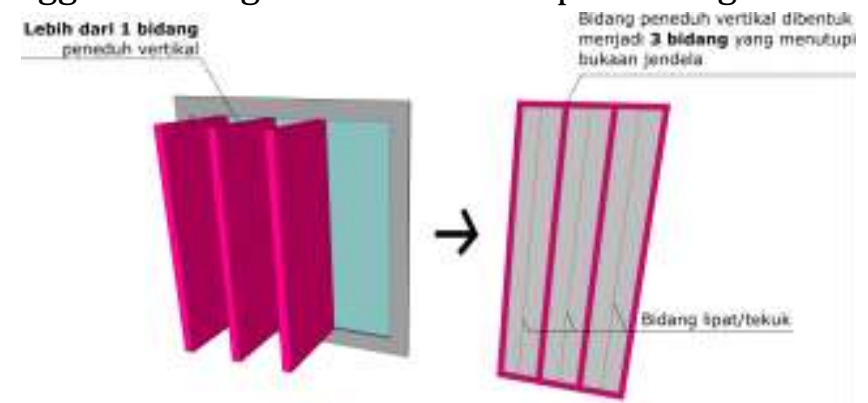

Gambar 5. Transformasi Sirip Matahari Vertikal 1, a) Sirip Matahari Vertikal, dan b) Hasil Transformasi Sirip Matahari Vertikal 1

\section{Sirip matahari vertikal 2}

Proses transformasi sirip matahari vertikal 2 dilakukan dengan membuat 2 (dua) bidang vertikal yang menutupi bukaan jendela dengan cara menyamping di kedua sisi jendela. Pada masing-masing bidang diletakkan 1 (satu) tungkai penggerak sebagai alat untuk melipat bidang.

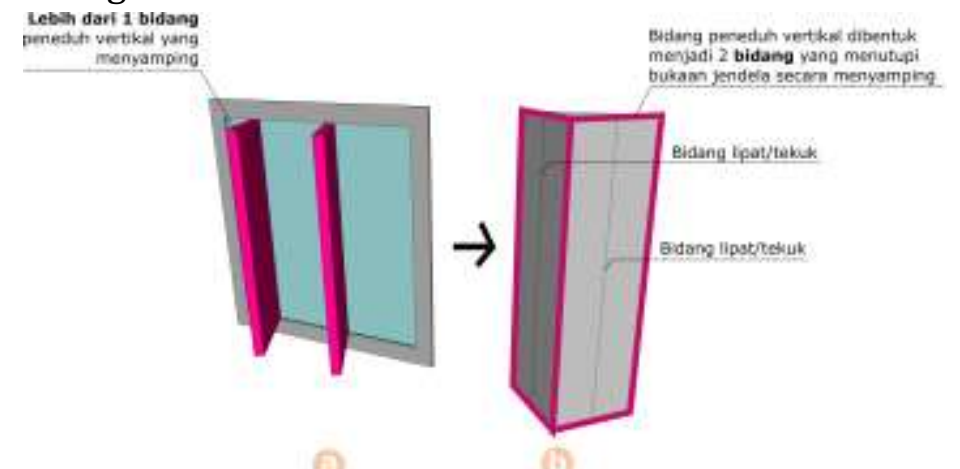

Gambar 6. Transformasi Sirip Matahari Vertikal 2, a) Sirip Matahari Vertikal, dan b) Hasil Transformasi Sirip Matahari Vertikal 2

\section{Sirip matahari egg crate}


Proses transformasi sirip matahari egg crate, dilakukan dengan membuat 16 (enam belas) bidang segitiga yang menutupi bukaan jendela. Pada masing-masing bidang diletakkan 16 (enam belas) tungkai penggerak sebagai alat untuk melipat bidang.

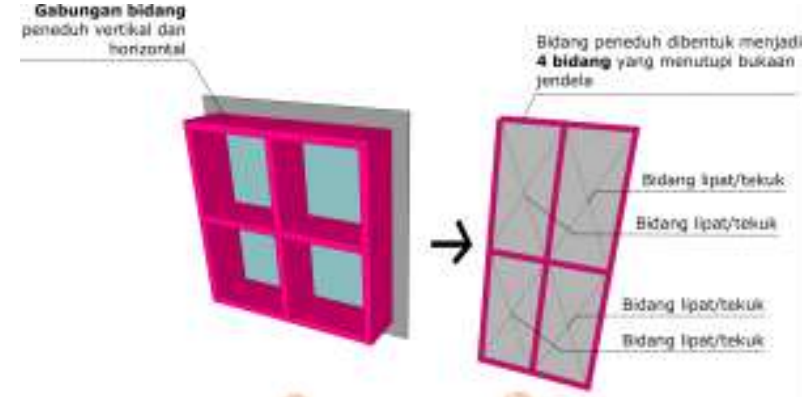

Gambar 7. Transformasi Sirip Matahari Egg Crate, a) Sirip Matahari Egg Crate, dan b) Hasil Transformasi Sirip Matahari Egg Crate

Adapun hasil pengembangan bentuk bidang sirip matahari, menghasilkan 6 model baru yang terdiri dari 3 (tiga) bentuk horizontal, 2 (dua) bentuk vertikal dan 1 (satu) bentuk egg crate. Hasil ragam transformasi bentuk sirip matahari kemudian dianalisa dengan kriteria desain yang dirumuskan berdasarkan kategori-kategori teoritis dan kemudian diambil bentuk terbaik untuk mendapatkan model sirip matahari yang akan dipakai pada fasad Gedung Kuliah Bersama V.

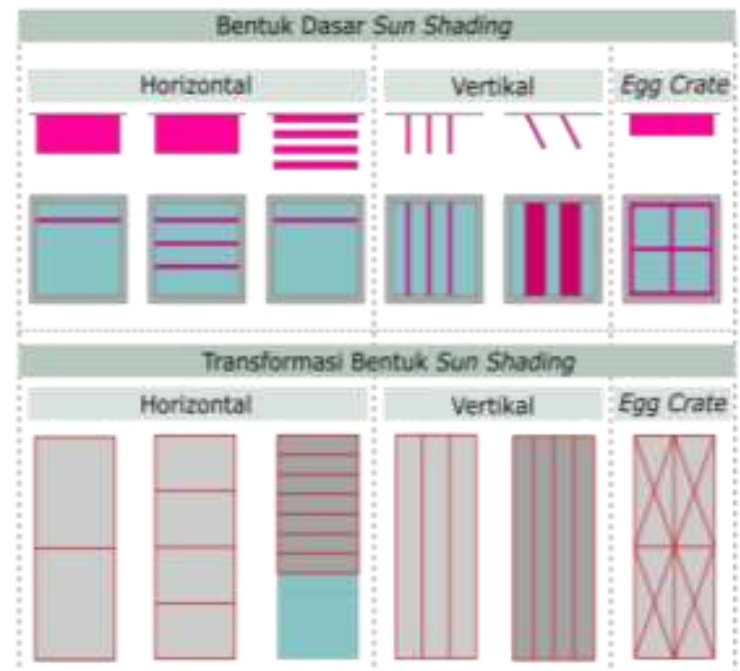

Gambar 8. Hasil Pengembangan Bentuk Dasar Sirip Matahari Sumber: Analisa Peneliti, 2019

Teori yang digunakan pada kriteria desain adalah Strategy For Adaptive Kinetic Patterns : Creating A Generative Design For Dynamic Solar Shading Systems (Majed dan Alkhayyat, 2013) dan Eksplorasi Sun Shading Fasad Apartemen Dengan Metode Transfer Arsitektur Biomimetik (Implementasi Putri Malu) (Ramawangsa, Soemardiono dan Setijanti, 2015). Kriteria desain yang akan dicapai dalam penelitian ini tersaji dalam tabel 1. 
Tabel 1. Kriteria Desain Sirip Matahari

\begin{tabular}{cll}
\hline No & \multicolumn{1}{c}{ Teori } & \multicolumn{1}{c}{ Kriteria Desain } \\
\hline 1 & $\begin{array}{l}\text { Jumlah tungkai kinetik yang efisien pada pergerakan } \\
\text { shading harus seminimal mungkin (Majed dan } \\
\text { Alkhayyat, 2013) }\end{array}$ & $\begin{array}{l}\text { Jumlah tungkai seminimal mungkin dengan } \\
\text { jumlah 1-5 tungkai }\end{array}$ \\
\hline 2 & $\begin{array}{l}\text { Integrasi bentuk geometris didasari atas persamaan } \\
\text { antar dua objek bentuk (Ramawangsa, Soemardiono } \\
\text { dan Setijanti, 2015) }\end{array}$ & $\begin{array}{l}\text { Kesamaan bentuk geometris antara desain } \\
\text { sirip matahari dengan fasad GB V }\end{array}$ \\
\hline
\end{tabular}

\section{Horizontal}

\section{a. Horizontal 1}

Bentuk sirip matahari horizontal 1 terdiri dari 2 bidang bayangan persegi dan 1 tungkai penggerak. Kelebihan dari bentuk ini adalah : 1) memiliki bentuk lipatan yang efisien terhadap sendi tungkai, 2) memiliki bentuk sederhana terdiri dari 1 (satu) bidang bayangan, dan 3) persentase bukaan yang besar pada jendela akibat lipatan bidang bayangan yang sederhana dan efisien. Sedangkan kekurangannya adalah bentuk ini sangat monoton dengan bentuk bidang pembayangan yang simetris.

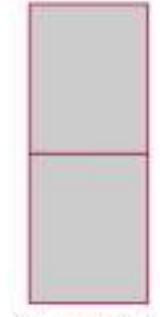

Kondisi Tertutup (2)

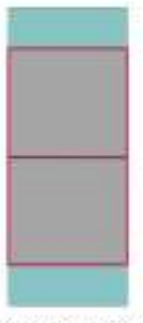

Kondisi $30 \%$

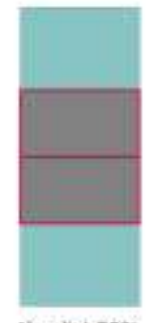

Kondisi SD3\%

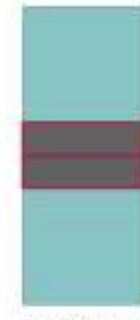

Kondisi 809

TAMPAK DEPAN

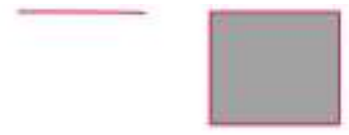

Kondisł Tertutup

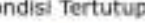

Kondisi $30 \%$

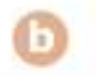

Gambar 9. Bentuk Lipatan Sirip Matahari Horizontal 1

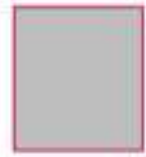

Kondisi $50 \%$

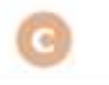

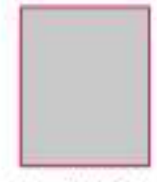

Kandisi $80 \%$

TAMPAK ATAS

Pada bentuk sirip matahari horizontal 1 terdiri dari 1 tungkai penggerak pada bidang lipatan yang terletak di tengah model sirip matahari sebagai alat pelipat bidang dan sangat sesuai dengan kriteria desain penggunaan jumlah tungkai yang seminimal mungkin. Integrasi bentuk sirip matahari horizontal 1 memiliki kesamaan dengan bentuk geometris bidang fasad Gedung Kuliah Bersama V yang berbentuk persegi. Secara keseluruhan bentuk sirip matahari ini memenuhi kriteria dengan jumlah tungkai kurang dari 5 tungkai dan bentuk yang simetris dengan fasad.

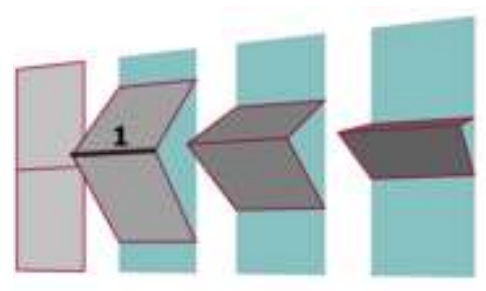

(a)

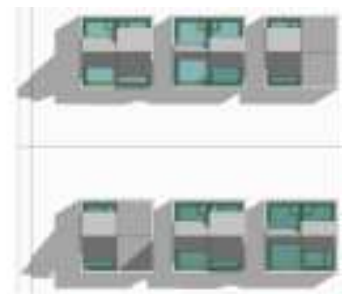

(1)

Gambar 10. a) Jumlah Tungkai Penggerak, dan b) Integrasi Bentuk Lipatan Sirip Matahari Horizontal 1 Dengan Fasad Gedung Kuliah Bersama V

b. Horizontal 2

Bentuk sirip matahari horizontal 2 terdiri dari 4 bidang bayangan persegi dan 2 tungkai penggerak. Kelebihan dari bentuk ini adalah : 1) memiliki bentuk lipatan yang 
efisien terhadap sendi tungkai, 2) memiliki bentuk sederhana terdiri dari 2 (dua) bidang bayangan, dan 3) persentase bukaan yang besar pada jendela akibat lipatan bidang bayangan yang sederhana dan efisien. Sedangkan kekurangannya adalah bentuk ini sangat monoton dengan bentuk bidang pembayangan yang simetris.
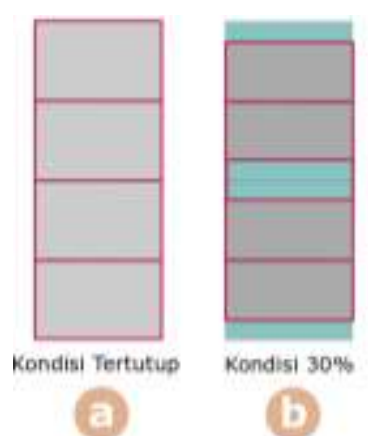
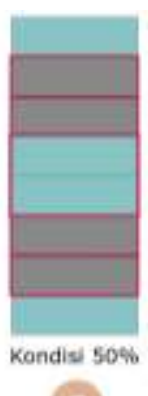

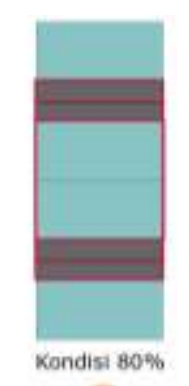

TAMPAK DEPAN

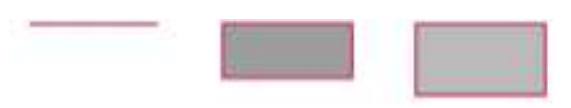

Kondisi Tertutup Kondisi $30 \%$ Kondisi $50 \%$

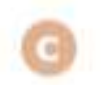

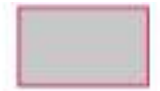

Kondisi $80 \%$

Gambar 11. Bentuk Lipatan Sirip Matahari Horizontal 2

Pada bentuk sirip matahari horizontal 2 (dua), model ini memiliki 2 (dua) bidang bayangan yang tersusun secara vertikal. Masing-masing bidang memiliki 1 tungkai penggerak sehingga secara keseluruhan berjumlah 2 tungkai penggerak sebagai pelipat bidang bayangan. Bentuk model ini sesuai dengan bidang geometris fasad Gedung Kuliah Bersama V. Secara keseluruhan bentuk sirip matahari ini memenuhi kriteria dengan jumlah tungkai kurang dari 5 tungkai dan bentuk yang simetris dengan fasad.
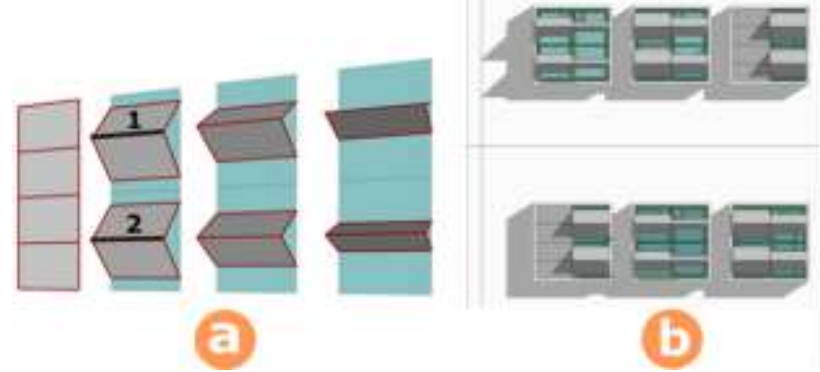

Gambar 12. a) Jumlah Tungkai Penggerak, dan b) Integrasi Bentuk Lipatan Sirip Matahari Horizontal 2 dengan Fasad Gedung Kuliah Bersama V

\section{c. Horizontal 3}

Bentuk sirip matahari horizontal 3 terdiri dari 3 bidang bayangan persegi dan 3 tungkai penggerak. Kelebihan dari bentuk ini adalah : 1) memiliki bentuk lipatan membujur ke depan jendela yang berbeda dengan bentuk horizontal 1 dan 2, 2) persentase bukaan yang besar pada jendela akibat lipatan bidang bayangan yang sederhana dan efisien. Sedangkan kekurangannya adalah : 1) bentuk ini memiliki bidang bayangan yang cukup banyak yang berpengaruh dengan jumlah tungkai penggerak, 2) tidak semua bidang jendela tertutupi oleh bidang bayangan akibat bentuk sirip matahari yang membujur ke depan. 

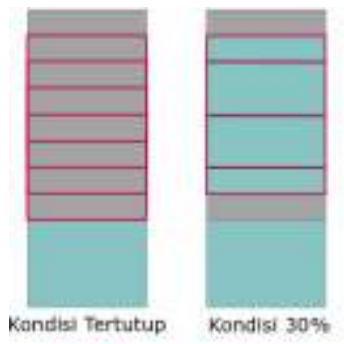

(b)

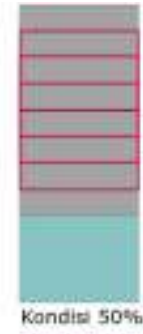

(a)

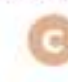

TAMPAK DEPAN

Gambar 13. Bentuk Lipatan Sirip Matahari Horizontal 3

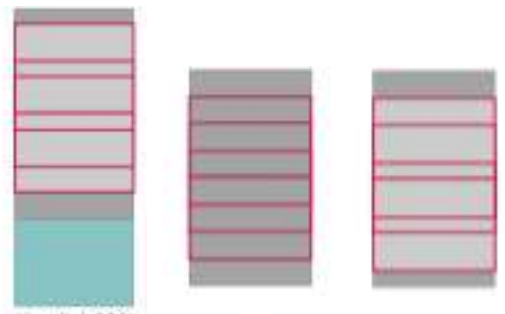

Kandisi $80 \%$

Kondisi Tertutup

Kondisi $30 \%$

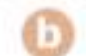

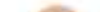

TAMPAK ATAS

Tipe sirip matahari horizontal 3 (tiga) terdiri dari 3 bidang bayangan dengan posisi membujur kedepan, sehingga terdapat celah pada bidang jendela. Model ini memiliki 3 tungkai penggerak pada 3 bidang lipatan. Bentuk geometris sirip matahari, tidak memiliki kesamaan dengan fasad bangunan akibat bentuk yang tidak beraturan. Secara keseluruhan bentuk sirip matahari ini tidak memenuhi kriteria karena bentuk geometris sirip matahari yang berbeda dengan bentuk fasad Gedung Kuliah Bersama $\mathrm{V}$ yang cenderung datar dan simetris.

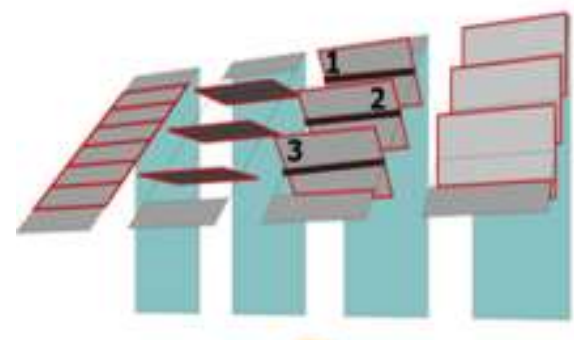

둔

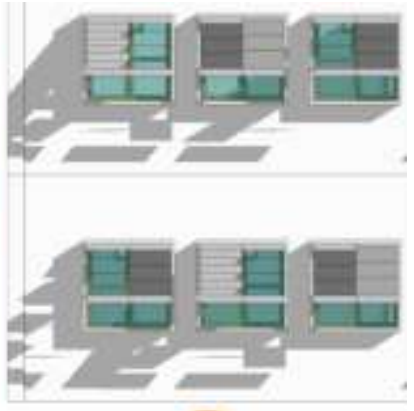

(3)

Gambar 14. a) Jumlah Tungkai Penggerak, dan b) Integrasi Bentuk Lipatan Sirip Matahari Horizontal 3 dengan Fasad Gedung Kuliah Bersama V

\section{Vertikal}

\section{a. Vertikal 1}

Bentuk sirip matahari vertikal 1 terdiri dari 6 bidang bayangan persegi panjang dan 3 tungkai penggerak. Kelebihan dari bentuk ini adalah : 1) memiliki bentuk lipatan yang efisien terhadap sendi tungkai, 2) memiliki bentuk sederhana terdiri dari 3 (tiga) bidang bayangan, dan 3) persentase bukaan yang besar pada jendela akibat lipatan bidang yang sederhana dan efisien. Sedangkan kekurangannya adalah : 1) bentuk ini sangat monoton dengan bentuk bidang pembayangan yang simetris, dan 2) memiliki jumlah bidang yang banyak. 

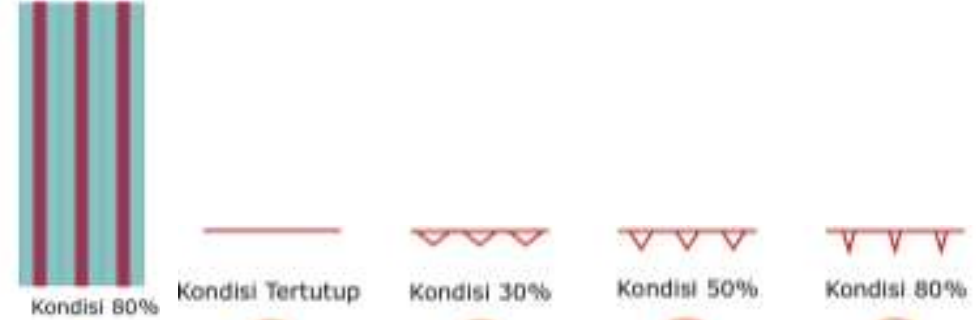

TAMPAK DEPAN
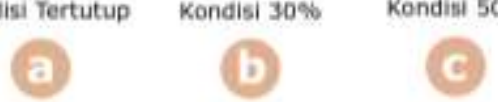

Kondisi $80 \%$

Gambar 15. Bentuk Lipatan Sirip Matahari Vertikal 1

Tipe sirip matahari vertikal 1 (satu) terdiri dari 3 bidang bayangan yang memanjang secara vertikal dan 1 tungkai pada masing-masing bidang dengan total 3 tungkai penggerak. Bentuk geometris sirip matahari memiliki kesamaan dengan fasad Gedung Kuliah Bersama $\mathrm{V}$ yang berbentuk datar dan persegi simetris. Secara keseluruhan bentuk sirip matahari ini memenuhi kriteria dengan jumlah tungkai kurang dari 5 tungkai dan bentuk yang simetris dengan fasad.
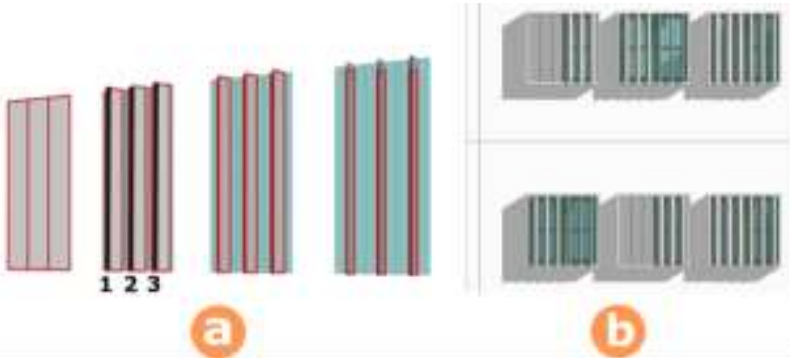

Gambar 16. a) Jumlah Tungkai Penggerak, dan b) Integrasi Bentuk Lipatan Sirip Matahari Vertikal 1 Dengan Fasad Gedung Kuliah Bersama V

b. Vertikal 2

Bentuk sirip matahari vertikal 2 terdiri dari 4 bidang bayangan persegi panjang dan 2 tungkai penggerak. Kelebihan dari bentuk ini adalah : 1) memiliki bentuk lipatan yang efisien terhadap sendi tungkai, 2) memiliki bentuk sederhana terdiri dari 2 (dua) bidang bayangan, dan 3) persentase bukaan yang besar pada jendela akibat bentuk lipatan bidang yang sederhana dan efisien. Sedangkan kekurangannya adalah bentuk ini sangat monoton dengan bentuk bidang pembayangan yang simetris.
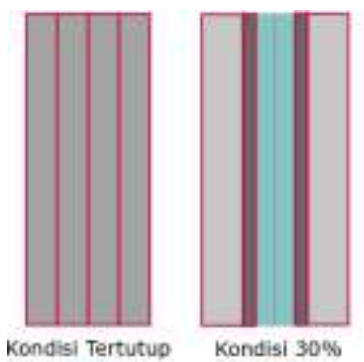

(b)

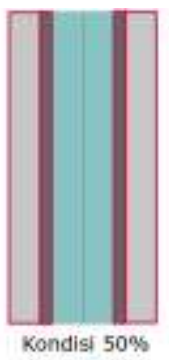

TAMPAK DEPAN

Gambar 17. Bentuk Lipatan Sirip Matahari Vertikal 2
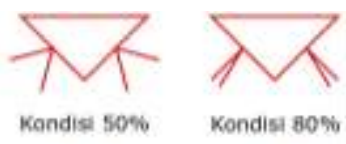

TAMPAK ATAS 
Pada bentuk sirip matahari vertikal 2 (dua), tipe ini memiliki 2 (dua) bidang bayangan yang tersusun memanjang secara vertikal. Masing-masing bidang memiliki 1 tungkai penggerak sehingga secara keseluruhan berjumlah 2 tungkai penggerak sebagai pelipat bidang bayangan . Model ini sesuai dengan bidang geometris fasad Gedung Kuliah Bersama V. Secara keseluruhan bentuk sirip matahari ini memenuhi kriteria dengan jumlah tungkai kurang dari 5 tungkai dan bentuk yang simetris dengan fasad.

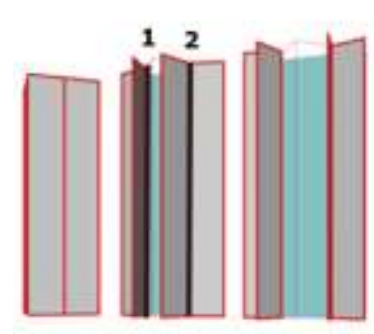

둔
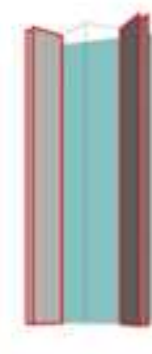

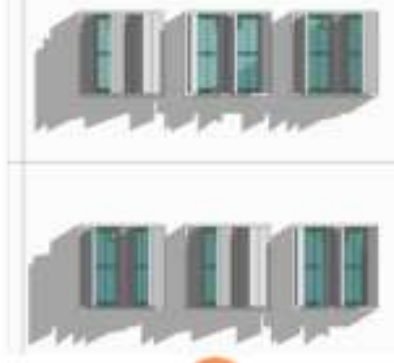

(1)

Gambar 18. a) Jumlah Tungkai Penggerak, dan b) Integrasi Bentuk Lipatan Sirip Matahari Vertikal 2 Dengan Fasad Gedung Kuliah Bersama V

\section{Egg crate}

Bentuk sirip matahari egg crate terdiri dari 16 bidang bayangan persegi panjang dan 16 tungkai penggerak. Kelebihan dari bentuk ini adalah : 1) memiliki bentuk lipatan yang berbeda dengan bentuk horizontal dan vertikal yang tersusun dari bidang segitiga, dan 2) persentase bukaan yang besar pada jendela akibat lipatan bidang bayangan yang sederhana dan efisien. Sedangkan kekurangannya adalah 1) bentuk ini sangat monoton dengan bentuk bidang pembayangan yang simetris, dan 2) memiliki bidang bayangan yang banyak dalam 1 modul sirip matahari sejumlah 16 bidang.

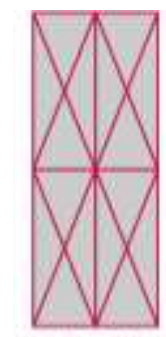

Kondisi Tertutup

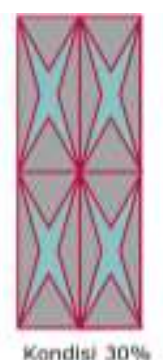

(b)

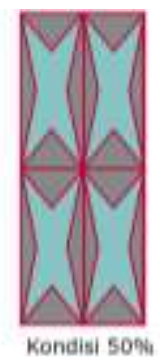

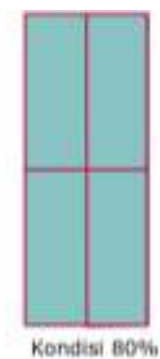

TAMPAK DEPAN

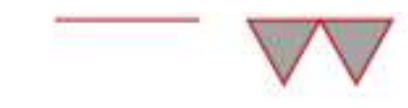

Kondisi Tertutup Kondisi $30 \%$

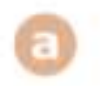

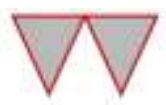

Kondisi $50 \%$

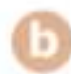

Gambar 19. Bentuk Lipatan Sirip Matahari Egg Crate

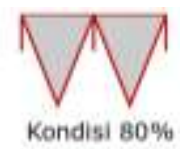

TAMPAK ATAS

Bentuk sirip matahari egg crate tersusun atas 16 bidang bayangan dengan tungkai penggerak sejumlah 16 tungkai. Bentuk geometris bidang tidak memiliki kesamaan dengan fasad Gedung Kuliah Bersama V akibat bentuk yang tidak beraturan. Secara keseluruhan sirip matahari egg crate ini tidak memenuhi kriteria akibat banyaknya jumlah tungkai dan bentuk dasar bidang yang berbeda dengan bentuk fasad bangunan. 

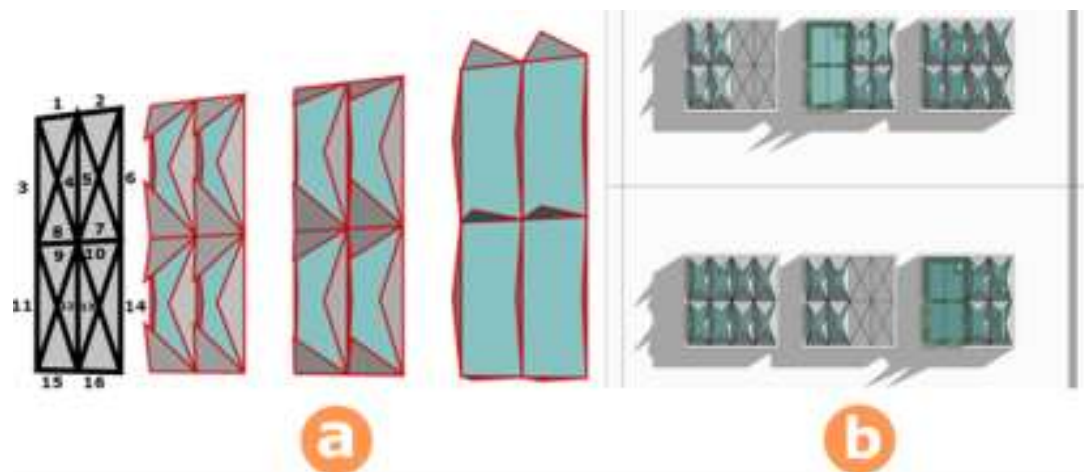

Gambar 20. a) Jumlah Tungkai Penggerak, dan b) Integrasi Bentuk Lipatan Sirip Matahari Egg Crate dengan Fasad Gedung Kuliah Bersama V

\section{B. Pemilihan Bentukan Sirip Matahari}

Berdasarkan hasil eksplorasi bentuk sirip matahari yang telah dilakukan pada bagian sebelumnya, terdapat 4 (empat) dari 6 (enam) sirip matahari yang memenuhi kriteria dengan parameter jumlah tungkai dan integrasi bentuk bidang bayangan terhadap fasad bangunan GB V. Namun diantara 4 (empat) bentuk sirip matahari, dilakukan pemilihan 1 (satu) bentuk yang terbaik dengan cara memilih jumlah tungkai penggerak lebih sedikit yang sesuai dengan teori Majed (2013) yang menyebutkan bahwa jumlah tungkai kinetik yang efisien pada pergerakan bidang bayangan harus seminimal mungkin (Majed dan Alkhayyat, 2013). Berdasarkan teori ini, sirip matahari yang memiliki jumlah tungkai paling sedikit adalah bentuk horizontal 1 dengan jumlah tungkai penggerak sebanyak 1 (satu) tungkai.

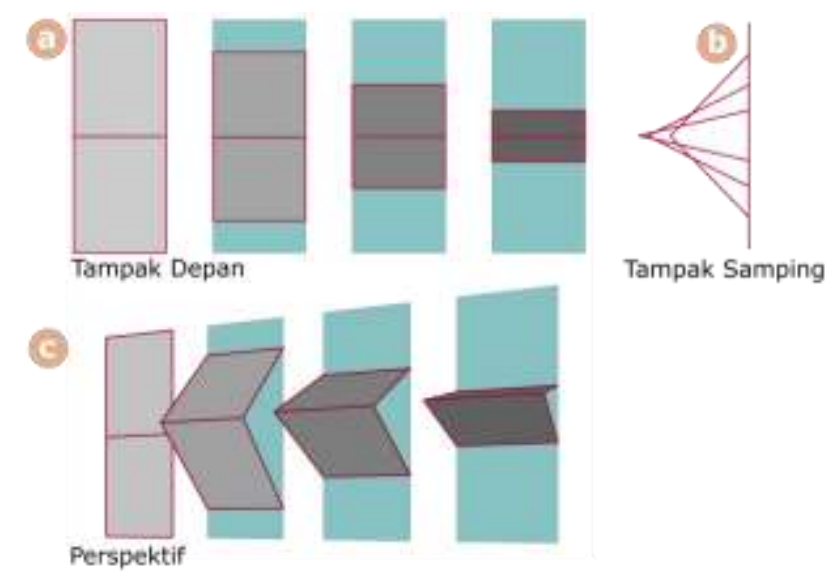

Gambar 21. Ragam Bentuk Lipatan Sirip Matahari Horizontal 1

\section{Konsep Peletakkan Sirip Matahari di Gedung Kuliah Bersama V}

Berdasarkan kondisi eksisting Gedung Kuliah Bersama V yang memiliki masalah kelebihan paparan matahari pada sisi kanan dan kiri bangunan akibat sering terpapar cahaya matahari langsung dan minimnya elemen pembayangan pada sisi tersebut, maka peletakkan sirip matahari horizontal 1 diletakkan pada sisi kanan dan kiri bangunan. 


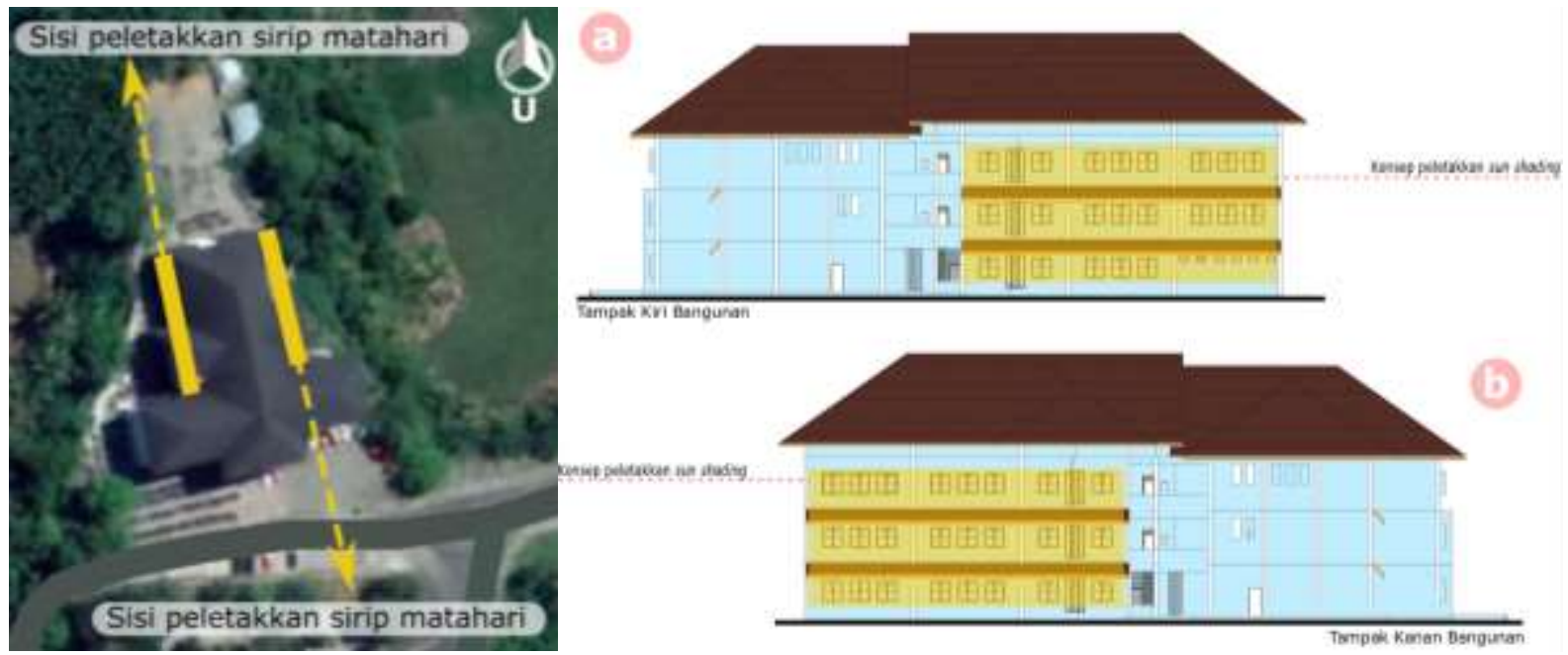

Gambar 22. Posisi Sirip Matahari pada Jendela Gedung Kuliah Bersama V

Peletakkan sirip matahari berfokus pada bagian luar bukaan jendela dengan jarak panel dengan dinding selebar $80 \mathrm{~cm}$. Hal ini bertujuan untuk membuat jarak bukaan daun jendela dan mendapatkan penghawaan pasif dari luar bangunan ke dalam bangunan serta perawatan terhadap bidang sirip matahari.

\section{KESIMPULAN}

Hasil penelitian yang didapat adalah ragam bentuk lipatan pada sirip matahari dengan penambahan sistem mekanisme tungkai pada beberapa sisi bidang dan pemilihan material yang mampu mengkondisikan aliran angin ke dalam bangunan. Bentuk sirip matahari yang sesuai dengan bentuk fasad Gedung Kuliah Bersama V dan jumlah tungkai yang paling sedikit adalah bentuk horizontal 1 yang memenuhi kriteria dengan jumlah 1 (satu) tungkai dan bentuk yang simetris dengan bentuk fasad bangunan. Jumlah tungkai pada bidang lipat yang baik harus seminimal mungkin untuk efisiensi pergerakan bidang sirip matahari.

Kondisi bentuk fasad Gedung Kuliah Bersama V yang minim elemen pembayangan dengan bentuk yang cenderung datar pada sisi kanan dan sisi kiri bangunan yang merupakan bagian yang sering terpapar cahaya matahari langsung akibat jalur lintasan matahari yang ada, maka desain sirip matahari horizontal 1 dapat diaplikasikan pada sisi tersebut serta diletakkan pada sisi terluar jendela bangunan dengan jarak $80 \mathrm{~cm}$ dari dinding bangunan. 


\section{DAFTAR REFERENSI}

Ching, F. D. (2008) "Arsitektur : Bentuk, Ruang dan Tatanan". Edisi 3. Jakarta, Indonesia: Erlangga.

Dewi, C. P., Budi, J. dan Choirotin, I. (2018) "Optimalisasi Kinerja Solar Shading Sebagai Usaha Menurunkan Solar Gain Pada Bangunan", Jurnal RUAS, 16(2), hal. 42-48.

Ishak, M. T. (2013) “Pengendalian Silau Terhadap Kenyamanan Visual Dalam Ruang”, Jupiter, 12(4), hal. 27-36.

Krier, R. (2001) Komposisi Arsitektur. Jakarta, Indonesia: Erlangga.

Kusumawati M., L. (2016) "Shading Device Design Based On Sun Potition and Indoor Lighting Requirements", In International Seminar Livable Space Applying Local Knowledge For Livable Space. Jakarta, Indonesia: Universitas Trisakti, hal. 193-198.

Lechner, N. (2001) Heating, Cooling, Lighting: Design Methods For Architects. 2th Edn. New York: John Wiley \& Sons.

Majed, J. and Alkhayyat, J. (2013) Strategy For Adaptive Kinetic Patterns : Creating A Generative Design For Dynamic Solar Shading Systems. University Of Salford.

Masruchin, F. R. dan Mufidah (2019) "Optimasi Pencahayaan Alami Pada Studio Arsitektur di Universitas 17 Agustus 1945 Surabaya", Jurnal Hasil Penelitian (Jhp17), 04(02), hal. 159-165.

Menteri Kesehatan Republik Indonesia (2002) "Persyaratan Kesehatan Lingkungan Kerja Perkantoran Industri". Indonesia.

Prayoga, H. A. (2014) "Intensitas Pencahayaan dan Kelainan Refraksi Mata Terhadap Kelelahan Mata", KESMAS, Jurnal Kesehatan Masyarakat Nasional, 9(16), hal. 131-136.

Purwantiasning, A. W. (2014) "Eksplorasi Arsitektur Sebagai Salah Satu Metode Dalam Proses Belajar Mengajar Mahasiswa Aktif di Jurusan Arsitektur Universitas Muhammadiyah Jakarta", Jurnal Arsitektur Universitas Bandar Lampung, 4(2), hal. 40-47.

Ramawangsa, P. A. dan Prihatiningrum, A. (2019) "Persepsi Mahasiswa Terhadap Kenyamanan Visual Pencahayaan Alami Pada Ruang Kelas (Studi Kasus Gedung Kuliah Bersama V (Lima), Universitas Bengkulu)", Pada Seminar Nasional, Inovasi, Teknologi Dan Aplikasi (Senitia) 2019. Bengkulu, Indonesia: Fakultas Teknik, Universitas Bengkulu, hal. 52-57.

Ramawangsa, P. A., Soemardiono, B. dan Setijanti, P. (2015) Eksplorasi Sun Shading Fasad Apartemen Dengan Metode Transfer Arsitektur Biomimetik (Implementasi Putri Malu). M.Ars Thesis, Institut Teknologi Sepuluh Nopember.

Saymote, P. (2016) “Google Sketch Up : A Powerful Tool For 3d Mapping and Modeling”, In International Journal of Computer Application And Engineering Technology, Volume 5, Pp. 377-382. 